\begin{tabular}{|l|l|l||}
\hline \multicolumn{2}{|c|}{ PublisherInfo } \\
\hline \hline PublisherName & $:$ & BioMed Central \\
\hline \hline PublisherLocation & $:$ & London \\
\hline \hline PublisherImprintName & $:$ & BioMed Central \\
\hline \hline
\end{tabular}

\title{
Platypus has 10 sex chromosomes
}

\begin{tabular}{||l|l|l||}
\hline \multicolumn{2}{|c|}{ ArticleInfo } \\
\hline \hline ArticleID & $:$ & 5014 \\
\hline \hline ArticleDOI & $:$ & $10.1186 /$ gb-spotlight-20041029-01 \\
\hline \hline ArticleCitationID & $:$ & spotlight-20041029-01 \\
\hline \hline ArticleSequenceNumber & $:$ & 77 \\
\hline \hline ArticleCategory & $:$ & Research news \\
\hline \hline ArticleFirstPage & $:$ & 1 \\
\hline \hline ArticleLastPage & $:$ & 3 \\
\hline \hline & $:$ & RegistrationDate : 2004-10-29 \\
ArticleHistory & $:$ & OnlineDate \\
\hline \hline ArticleCopyright & $:$ & BioMed Central Ltd2004-10-29 \\
\hline \hline ArticleGrants & $:$ & \\
\hline \hline ArticleContext & $:$ & 130595511 \\
\hline \hline
\end{tabular}




\section{Nick Atkinson}

Email: nwa@entangled.org

A team of scientists from Australia and the United Kingdom has finally elucidated the strange sex chromosome system of the duck-billed platypus. The first study, the findings of which are published this week in Proceedings of the National Academy of Sciences, demonstrates that the platypus has 10 sex chromosomes, rather than the single pair usually found in mammals (Proc Natl Acad Sci USA 2004, DOI:10.1073/pnas.0405702101). Results of a second study, appearing this week in Nature, detail the way the chromosomes segregate during male meiosis to determine the sex of the zygote (Nature 2004, DOI:10.1038/nature03021).

"The platypus has long been known to have an unusual multiple set of sex chromosomes," said the University of Melbourne's professor Marilyn Renfree, who was not involved in the studies. However, the use of fluorescence in situ hybridization (FISH) confirmed how the ten elements segregate. "Remarkably, the five X chromosomes go into one cell, and the five $\mathrm{Y}$ into another," she continued. "This results in two kinds of sperm - half with XXXXX that determine female young and half with YYYYY that determine male young."

"This sex chromosome system is unique in mammals," said the Australian National University's Frank Grützner, lead author of the Nature paper. "The only way to ensure that five X chromosomes end up in one sperm and five $Y$ chromosomes in another is for all of the sex chromosomes to assemble in a certain pattern - X1Y1X2Y2X3Y3X4Y4X5Y5 - during meiosis. That's precisely what we found - a chain of alternating $\mathrm{X}$ and $\mathrm{Y}$ chromosomes."

Willem Rens, lead author on paper in $P N A S$, said that his team used FISH to visualize each chromosome. "The paints are hybridized to metaphase cell preparations and reveal which chromosomes are present," said Rens, of Cambridge University's Resource Centre for Comparative Genomics. The technique allowed the researchers to discover how sex is determined at the chromosomal level, he told us, although at the level of the gene it remains a mystery.

Peter Temple-Smith, at the University of Melbourne, met the new findings with enthusiasm. "The use of several extremely powerful, recently developed genetic techniques have unlocked some of the longheld secrets of sex determination in monotremes," he said. "The results suggest an otherwise unexpected evolutionary connection between bird and mammal sex chromosomes."

"The complexity and intricacy of this system is mind-blowing," said Katherine Belov, of the Australian Museum's Evolutionary Biology Unit. "The fact that monotremes can manage such a large number of chromosomes is interesting in itself, but these findings also shed important light on the evolution of mammalian sex chromosomes."

Belov, who was not involved in the studies, noted that mammalian sex determination is the result of the $S R Y$ gene on the Y chromosome, which controls the formation of testes. However, it is thought that sex determination in birds is controlled in a dosage-dependent manner: heterogametic females only have one copy of the DMRT1 gene, whereas the homogametic males have two.

"The most surprising finding is that the $\mathrm{X}$ at one end of the platypus sex chromosome chain has genes that are orthologous with those on the human X-chromosome, whereas genes on chromosomes at the 
other end of the chain are homologous with those on the bird Z chromosome," said Renfree. "This suggests that the sex determination systems in mammals and birds are not as different as we have always thought," she continued. "Mammal sex chromosomes may well have co-evolved with those of birds, and the platypus could be the key to finding out."

"The monotremes represent the last few species of a much wider radiation that diverged from the other mammals 220 to 180 million years ago," said Temple-Smith, who was not involved in the studies. "They presumably retain some characteristics of their therapsid reptilian history and are thus ideally positioned to provide a unique view of mammalian evolution."

Belov thinks that monotremes might be a "missing link." It has long been believed that mammalian and avian sex chromosomes evolved from different autosomes, she said. "By demonstrating the similarities between both systems Grützner, Rens and colleagues have blown that theory out of the water," she told us. "The elucidation of sex determination in monotremes is likely to lead to groundbreaking revelations in other mammals and in birds."

\section{References}

1. Holding C: Sex and the X Genome Biology, February 2, 2004., [http://genomebiology.com/ researchnews/default.asp?arx_id=gb-spotlight-20040203-01]

2. Proceedings of the National Academy of Sciences USA, [http://www.pnas.org]

3. Nature, [http://www.nature.com]

4. Frank Grützner, [http://www.rsbs.anu.edu.au/Profiles/Frank_Gruetzner/]

5. Fluorescence In Situ Hybridization, [http://www.accessexcellence.org/RC/VL/GG/fish.html]

6. Cambridge Resource Centre for Comparative Genomics, [http://www.vet.cam.ac.uk/genomics/]

7. Review of the monotreme fossil record and comparison of palaeontological and molecular data

8. Kreeger KY: Yes, biologically speaking, sex does matter The Scientist, January 7, 2002 , [http://www.the-scientist.com/yr2002/jan/research_020107.html]

This PDF file was created after publication. 